\title{
ВИЗНАЧЕННЯ ТЕРМІНІВ ЗРУЧНООБРОБЛЮВАНОСТІ ЦЕМЕНТОГРУНТУ
}

\section{DETERMINATION OF THE USEFULNESS OF CEMENTITIOUS SOIL}

Панасюк Я.І., к.т.н., доц., Маліков В.В. к.т.н., доц. (Луцький національний технічний університет)

Panasiuk Y.I., Ph.D. in Engineering, Associate Professor, Malikov V.V., Ph.D. in Engineering, Associate Professor (Lutsk National Technical University)

Експериментально доведено можливість прогнозування рівня падіння показників міцності залежно від втрати цементогрунтовими сумішами вологості при різних температурних умовах.

In the technology of placing cementitious road layers clothing it is important to have data on the convenience the work for this material. The period of convenient cementitious cultivation is determined by the time until the beginning of the cement production. The time required to seal the mortar from the fortified soil should be set up in advance, based on the expected air temperature during the work. It is obvious that the sealing of cement-mortar mixtures should be completed before crystallization bonds are formed as a result of cement hydration. This will enable the material to be sealed without destroying newly formed crystalline bonds and reducing its mechanical properties.

In carried out experimental studies in laboratory, conditions were created with the help of a thermowardrobe with forced air circulation. They were adopted in order to simulate the conditions transportation of the mixture to the work place. After 1, 2, 3 and 4 hours after holding the mixtures in the thermocouple, cylindrical specimens were formed from them and the average density of the samples was determined immediately, and after 28 days in a hydraulic bath, compressive strength and fracture strength were determined.

The obtained dependences allow to predict the level fall of strength indicators, depending on the loss cement-based mixtures of moisture under various temperature conditions. 
Thus, the obtained results indicate that the length of the technological process from the moment preparation of the cementious mixture to the end of its consolidation should be determined by the induction period, which can be provided with a slightly more amount of moisture in its composition, compared with the optimum. This will ensure the preservation physical and strength characteristics of the properties cementitious road layers clothing.

Ключові слова: грунт, цемент, міцність при стиску, зручнооброблюваність.

Keywords: soil, cement, compressive strength, comfortable handling.

У технології влаштування цементогрунтових шарів дорожнього одягу важливо мати дані щодо зручнооброблюваності цього матеріалу. Період зручнооброблюваності цементогрунтів визначається часом до початку тужавіння цементу. Час, потрібний для ущільнення суміші 3 укріпленого грунту, повинен бути встановлений завчасно, виходячи з очікуваної температури повітря у процесі роботи. Очевидно, що ущільнення цементогрунтових сумішей повинно бути завершено до того, як утворяться кристалізаційні зв'язки в результаті гідратації цементу. Це дасть можливість проводити ущільнення матеріалу без руйнувань новоутворених кристалізаційних зв'язків i зниження його механічних властивостей.

При проведенні експериментальних досліджень у лабораторних умовах були прийняті умови, які створювали за допомогою термошафи 3 примусовою циркуляцією повітря. Вони були прийняті з метою моделювання умов транспортування суміші до місця виконання робіт. Через 1, 2, 3 і 4 години після витримування сумішей в термокамері з них формували циліндричні зразки та відразу визначали середню щільність зразків, а після 28 діб тужавіння в гідравлічній ванні визначали міцність при стиску та при розколі.

Склад цементогрунтових сумішей складався із супіску піщанистого, 12\% цементу від маси сухого грунту та $10 \%$ води від маси сухої цементогрунтової суміші.

Цементогрунтові суміші було приготовано згідно [1-4], та заформовано зразки-циліндри розміром $5 \times 5$ см. 
Результати експериментальних досліджень (рис. 1) показують, що середня щільність зразків із досліджуваних цементогрунтових сумішей зменшується при збільшенні температури середовища, тривалості періоду знаходження сумішей у відповідних умовах від моменту приготування до моменту ущільнення. При цьому підвищення температури від $20^{\circ} \mathrm{C}$ до $30^{\circ} \mathrm{C}$ більш суттєво зменшує середню щільність цементогрунтів, ніж додаткова примусова циркуляція повітря при досліджуваних температурах.

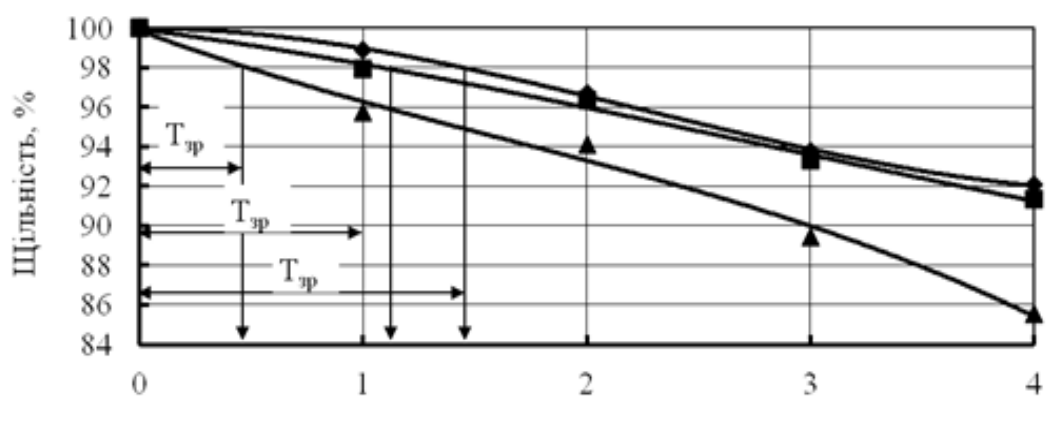

Час, год

ис. 1. Залежність величини зменшення середньої щільності цементогрунту від часу витримки суміші після іiі приготування:

- при $20^{\circ} \mathrm{C}, \boldsymbol{\square}$ - при $20^{\circ} \mathrm{C}$ з обдувом повітрям, $\boldsymbol{\Delta}$ - при $30^{\circ} \mathrm{C}$. $\left(\mathrm{T}_{\text {зр }}\right.$ - термін зручнооброблюваності)

Наприклад, після 4-х годинної витримки цементогрунтової суміші при $20^{\circ} \mathrm{C}$ з моменту іï приготування, середня щільність зразків зменшується на $7,95 \%$, при $30^{\circ} \mathrm{C}$ - на $14,45 \%$, а при $20^{\circ} \mathrm{C}$ спільно з примусовою циркуляцією повітря - на 8,68\%. Витримці цементогрунтової суміші при $20^{\circ} \mathrm{C}$ відповідає 87 хвилинний термін зручнооброблюваності, при $20^{\circ} \mathrm{C} \quad 3$ одночасною примусовою циркуляцією повітря - 64 хвилинний термін, а витримці при $30^{\circ} \mathrm{C}-$ 29 хвилинний термін.

Вказана тенденція підтверджується експериментально встановленими залежностями вологості даних систем від часу витримки сумішей (рис. 2.). 


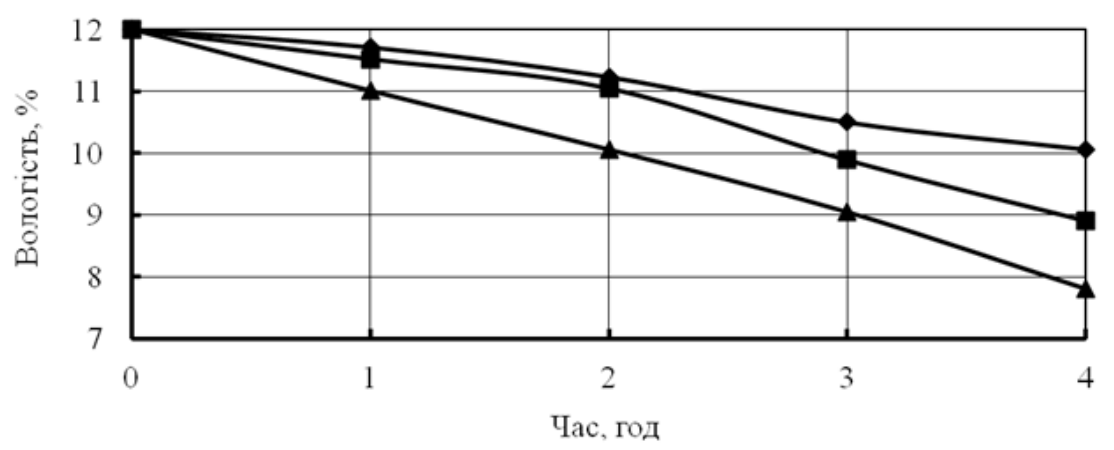

Рис. 2. Залежність вологості цементогрунтової суміші від часу їі витримки після приготування: $\bullet-$ при $20{ }^{\circ} \mathrm{C},-$ при $20{ }^{0} \mathrm{C} 3$ обдувом повітрям, $\boldsymbol{\Delta}-$ при $30{ }^{\circ} \mathrm{C}$

Результати дослідження впливу тривалості витримки при різних температурах досліджуваних цементогрунтових сумішей на показники міцності наведені на рис. 3-4. 3 наведених залежностей видно, що зі збільшенням тривалості витримки досліджуваних сумішей показники границі міцності при стиску та розколі зразків зменшуються. Зменшення показників міцності пов'язане $з$ тим, що впродовж витримки 3 сумішей випаровується вода, якої стає недостатньо для забезпечення максимальної щільності грунту при ущільненні та для повної гідратації цементу.

Границя міцності при розколі є більш чутливим критерієм до тривалості витримки сумішей в певних кліматичних умовах, порівняно з границею міцності при стиску. Якщо після 4-х годинної витримки цементогрунтової суміші при $20^{\circ} \mathrm{C}$ границя міцності при стиску цементогрунту знизилась на $28 \%$, то при розколі - на $38 \%$. 3 отриманих результатів видно, що на інтенсивність зменшення показників міцності впливають режими витримування сумішей до ущільнення. Найбільше падіння показників границі міцності при стиску та при розколі спостерігається у випадку витримки суміші при $30^{\circ} \mathrm{C}$, а найменше - при $20^{\circ} \mathrm{C}$. Витримка суміші при $20^{\circ} \mathrm{C} 3$ примусовою циркуляцією повітря займає проміжне положення. Тривалість витримки сумішей суттєво впливає на величину падіння показників міцності. Так, після витримки цементогрунтової суміші впродовж 1 години при $20^{\circ} \mathrm{C}$ і при $30^{\circ} \mathrm{C}$ різниця у значенні границі міцності при стиску становить $0,07 \mathrm{MПа,} \mathrm{а} \mathrm{при} \mathrm{розколі} \mathrm{-} \mathrm{0,03} \mathrm{МПа.}$ У той же час, після 4-х годин витримки цементогрунтової суміші в 
аналогічних кліматичних умовах різниця у значенні границі міцності при стиску становить 1,32 МПа і 0,09 МПа при розколі.

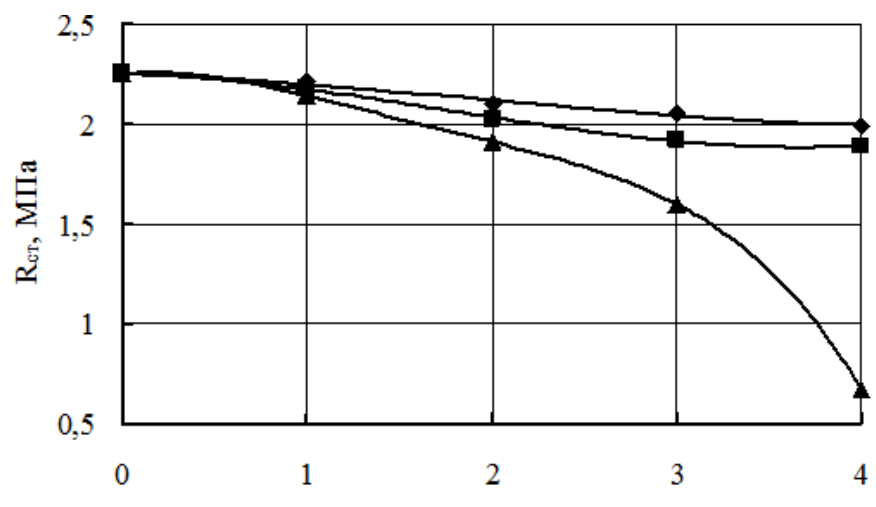

Час витримки суміші, години

Рис. 3. Залежність границі міцності при стиску $\left(\mathrm{R}_{\mathrm{cr}}\right)$ цементогрунту від часу витримки суміші: $\bullet-$ при $20{ }^{\circ} \mathrm{C}, \boldsymbol{\square}$ - при $20{ }^{\circ} \mathrm{C}$ з обдувом повітрям, $\boldsymbol{\Delta}$ - при $30{ }^{\circ} \mathrm{C}$

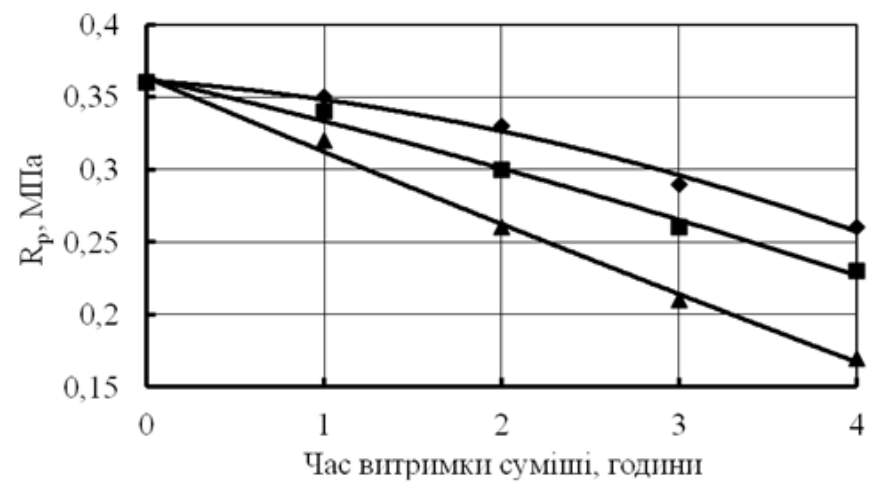

Рис. 4. Залежність границі міцності при розколі $\left(\mathrm{R}_{\mathrm{p}}\right)$ цементогрунту від часу витримки суміші: - при $20{ }^{0} \mathrm{C}, \boldsymbol{\square}$ - при $20{ }^{0} \mathrm{C}$ з обдувом повітрям, $\boldsymbol{\Delta}-$ при $30{ }^{\circ} \mathrm{C}$

Для досліджуваних цементогрунтових сумішей було встановлено, що витримка протягом 2 годин при $30^{\circ} \mathrm{C}$ еквівалентна 3 -м годинам витримки при $20^{\circ} \mathrm{C}$ з примусовим обдувом повітрям, або 4-м годинам витримки при $20^{\circ} \mathrm{C}$. Окрім того, 3 години витримки 
при $30^{\circ} \mathrm{C} \epsilon$ еквівалентним 4-м годинам витримки при $20^{\circ} \mathrm{C} 3$ примусовим обдувом повітрям, а також 1 година витримки при $30^{\circ} \mathrm{C}$ еквівалентна 2-м годинам витримки при $20^{\circ} \mathrm{C} 3$ примусовим обдувом повітрям, або еквівалентна 3-м годинам витримки при $20^{\circ} \mathrm{C}$, а також одна година витримки при $20^{\circ} \mathrm{C}$ з примусовим обдувом повітрям еквівалентна 2-м годинам витримки при $20^{\circ} \mathrm{C}$.

Отримані залежності дозволяють прогнозувати рівень падіння показників міцності залежно від втрати цементогрунтовими сумішами вологості при різних температурних умовах.

Таким чином, отримані результати свідчать про те, що тривалість технологічного процесу 3 моменту приготування цементогрунтової суміші до закінчення іï ущільнення повинна визначатись індукційним періодом, який може бути забезпечений дещо більшою кількістю вологи у пї складі, порівняно 3 оптимальною. При цьому буде забезпечено збереження фізичних i міцнісних показників властивостей цементогрунтових шарів дорожнього одягу.

\section{Список використаних джерел}

1. Шари дорожнього одягу 3 кам'яних матеріалів, відходів промисловості i грунтів укріплених цементом. Проектування та будівництво: ГБН В.2.3-37641918-554:2013. - К:Укравтодор-2013. - 43 с.

2. Споруди транспорту. Влаштування шарів дорожніх одягів 3 грунтів, укріплених в'яжучими матеріалами: ВБН В.2.3-218-541:2010. - К.: Укравтодор, 2010 - 39 с.

3. Смеси щебеночно-гравийно-песчаные и грунты, обработанные неорганическими вяжущими материалами, для дорожного и аэродромного строительства. Технические условия: ГОСТ 23558-94. - М., 1994. - 9 с.

4. Споруди транспорту. Дорожній одяг нежорсткого типу : ВБН В.2.3218-186-2004. - К.: Укравтодор, 2004. - 176 с. 